\title{
THE COPPER-GOLD VEIN DEPOSIT OF KIVIMAA AT TERVOLA, N-FINLAND
}

\author{
Pentti Rouhunkoski and Pauli Isokangas
}

\begin{abstract}
Rouhunkoski, Pentri and Isokangas, Pauli 1974: The copper-gold vein deposit of Kivimaa at Tervola, N-Finland. Bull. Geol. Soc. Finland 46, 29-35.

The Kivimaa ore vein in Northern Finland is located in a shear zone in a folded greenstone bed. The vein is c. 350 metres in length and varies from 1 to 6 metres in thickness. The central and most mineralized part of the vein was mined in 1969 , c. $18000 \mathrm{t}$ of ore were produced averaging $1.2 \% \mathrm{Cu}$ and $2 \mathrm{~g} / \mathrm{t} \mathrm{Au}$. Coarse-grained calcite and quartz form the base of the vein and the major ore minerals are pyrite, magnetite and chalcopyrite. Comparable with analogous sulphide-bearing veins in the Karelian metadiabases in Eastern Finland the Kivimaa ore vein is assumed to have formed as the final differentiate of initial spilitic greenstone magmatism.
\end{abstract}

Pentti Roubunkoski and Pauli Isokangas, Exploration Department, Outokumpu Co, P.O. Box 27, 02101 Tapiola, Finland.

\section{Introduction}

The Kivimaa ore deposit is situated in North Finland, in the commune of Tervola, $50 \mathrm{~km}$ northeast of the town of Kemi.

The average thickness of the till cover in the area is about 5 metres. Since exposures are rare, floats are important in estimating the distribution of the rock types and in evaluating the probability of the occurrence of an ore deposit. Impetus was given to explorational activities by the c. $100 \mathrm{~kg}$ ore float, from which a sample was sent to the Exploration Department of the Outokumpu Company by a farmer, Aarne Juntunen, in 1961. The sample assayed $3 \%$ copper and $100 \mathrm{~g} / \mathrm{t} \mathrm{Au}$.
The data obtained from the float suggested that it might have originated from a vein deposit with a quartz-carbonate base. A great number of greenstone and albite diabase floats were unearthed in the course of the detailed studies that were commenced immediately. The floats contained narrow veins and shoots composed of a material approximating that of the first float.

Observations on the striae and orientation studies on the pebbles in the till indicated that the upper till layer had been translated eastwards $\left(260^{\circ}\right)$. Consequently, the geological, geophysical and geochemical studies were concentrated on the drumlin terrain known as Kivimaa. Observations on the floats showed that significant amounts of pyrrhotite were occasionally present 
in the chalcopyrite-bearing veins, hence the emphasis was shifted to magnetic survey. However, the ore vein could not be detected by this method, because the greenstones and albite diabases in the area often contain heterogeneously distributed magnetite. The four holes drilled in 1962 did not intersect the vein.

In 1964, when the IP method had become established as one of the routine explorational methods, studies were reactivitated in the area. An IP anomaly, higher than the others, was spotted about $1 \mathrm{~km}$ west of the first ore float. Subsequent drilling and excavation proved that it was caused by an ore vein (Fig. 1). The mineralized vein is 350 metres in length and varies in thickness from 1 to 6 metres. The strike of the vein (W-E) is parallel to that of the general geologic structure with a dip of $15^{\circ}-$ $40^{\circ}$ to the north. It was estimated that the most high-grade central part of the vein totalled c. 20000 tons in situ, assaying $1.87 \%$ copper and $5.3 \mathrm{~g} / \mathrm{t} \mathrm{Au}$.

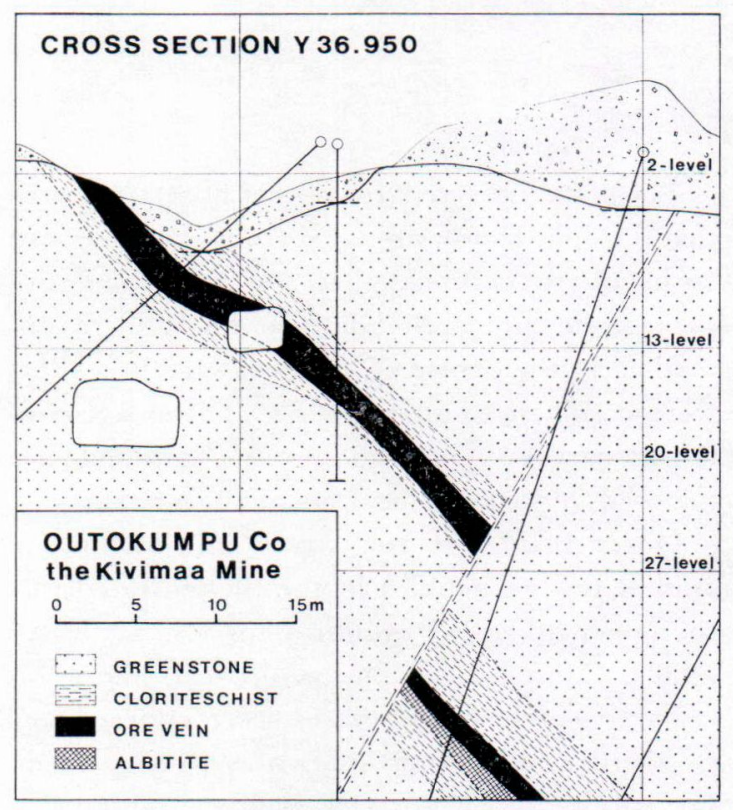

Fig. 1. Cross section of the ore zone.

\section{Exploitation}

Since this vein represented an unusual ore type in Finland it was decided to mine the best part of the ore to collect oregeologic information and to augment experience in exploitation.

The ore was mined in 1969 partly from an open pit and partly underground by a top slicing method, for which a ramp was driven to a depth of about 30 metres parallel to the vein. The mined ore was transported $250 \mathrm{~km}$ by lorry to the Vihanti mine where a goldbearing sulphide concentrate and a magnetite concentrate were produced from it. The concentrator treated 18000 tons of ore averaging $1.2 \%$ copper and $2 \mathrm{~g} / \mathrm{t} \mathrm{Au}$. The dilution was higher than anticipated owing to the fractured country rocks (Alarotu 1970).

\section{Geologic setting}

Kivimaa is located in the middle of the Peräpohja schist area, at the spot where the lower volcanic rocks of the geosynclinal series emerge in the Korpikylä anticlinal ridge (Mikkola 1949). According to Härme (1949), who has described the stratigraphy of the southern part of the Peräpohja schist area, the lowest sedimentary rock in the series is a thick quartzite layer overlain by a spilitic and amygdaloidal greenstone. It is underlain by a hypabyssal greenstone, i.e. albite diabase that intruded between the quartzite and the basement gneiss complex. On top of the extrusive greenstones there are stratified basic schists and thick layers of dolomite, with which abundant black schists are associated in the Kivimaa area. Phyllite occupies the highest position in the sedimentary sequence. Sakko (1971) has carried out age determinations on zircons in the albite diabases and a plot on a concordia diagram yields an age of $2150-2160$ M.y.

The Kivimaa ore deposit is located in the basic volcanic zone, in a place where, as the magnetic survey suggests, there is a vertex of and axial surface of a folded volcanic bed. Only 
the volcanics are of importance to the present study and, hence, they will be discussed at some length.

In general, the greenstone shows weak orientation. It is fine-grained and occasionally contains small amygdules filled with carbonate or chlorite. The amygdules may also have sulphides. In some places the fine-grained greenstones grade into coarse-grained metagabbros or ophitic diabases reprềsenting inner parts of the volcanic beds. Among them there are also dykes that have been interpreted as separate intrusives and whose coarse-grained inner parts grade into very finegrained marginal variants. Fine- and coarsegrained albitites often containing carbonates are also associated with the greenstone series. The contacts suggest that at least some of the albitites brecciate their country rocks. All the above rock types contain occasional narrow cross-cutting epidote, quartz and, above all, carbonate veins that may also have some sulphides. The feldspar in the greenstone is saussuritized albite or oligoclase. Hornblende, together with chlorite and occasional relics of pyroxene, is the predominant mafic mineral. Ilmenite with abundant titanite is common. Variable amounts of magnetite and pyrite are also encountered. Carbonate and apatite are the most common accessories. The effusive greenstones in the Peräpohja area also contain chalcocite in several places. In addition to its association with small quartz schlieren it occurs as a low-grade dissemination throughout the rock and seems to favour shear zones in particular.

\section{Ore deposit}

Carbonate and quartz predominate in the vein (Fig. 2.). According to the $\mathrm{X}$-ray diffraction studies, the carbonate is almost pure calcite, although the occasional occurrences of dolomite were also verified. Quartz and, above all, calcite are coarse-grained and the grain size may reach several centimetres. Calcite is grey, in places almost white or salmon pink in colour.

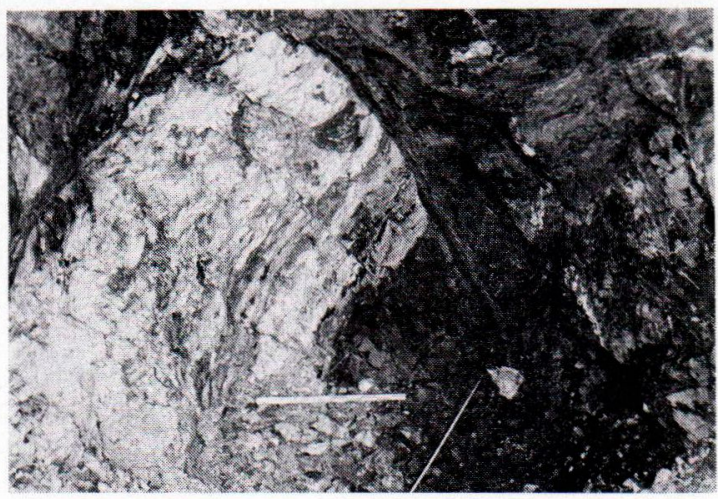

Fig. 2. Vein at the drift face on the +13 -level. The vein is cut by a fault zone.

A carbonate sample from the +27 level $(y=$ 37.055) had a composition of $53.5 \% \mathrm{CaO}, 0.4 \%$ $\mathrm{MgO}, 2.1 \% \mathrm{FeO}$ and $1.5 \% \mathrm{MnO}$. In addition to the above gangue minerals, there is chlorite and occasionally sericite.

Fine-grained albite-carbonate rock was encountered in some drill holes intersecting the extension of the vein along the dip (see Fig. 1.):

The major ore minerals are pyrite, magnetite and chalcopyrite. In general, they show a heterogeneous distribution in the vein (Fig. 3.). Arsenopyrite, pyrrhotite, ilmenite, rutile, bismuthinite, native bismuth and gold occur as accessories. Galena was encountered in a shear

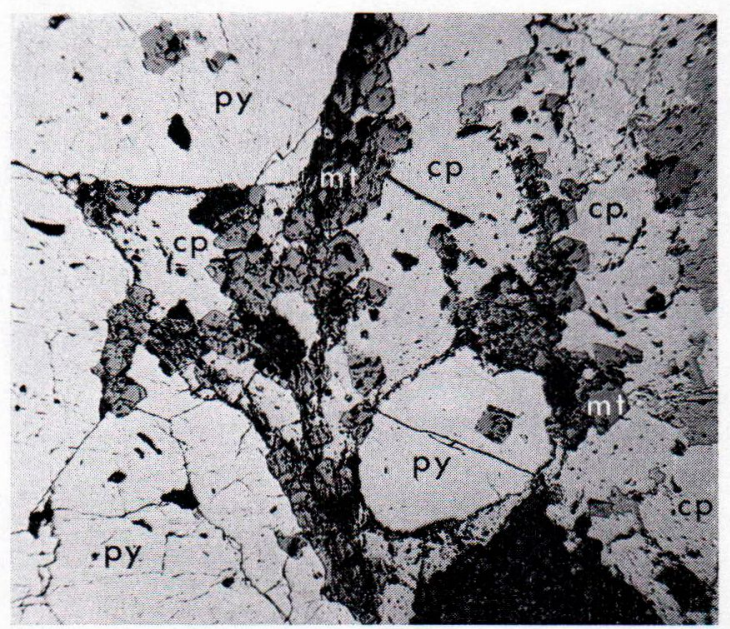

Fig. 3. Photomicrograph of the mode of occurrence of the main ore minerals in the vein. Magn. $10 \times$. py $=$ pyrite, $\mathrm{cp}=$ chalcopyrite, $\mathrm{mt}=$ magnetite. 
about $1 \mathrm{~cm}$ thick. As secondary alteration products there are marcasite, hematite, goettite, limonite and covelline. Pyrite occurs in more or less idiomorphic grains displaying cataclastic deformation. The diameter of the crystals may be as much as several centimetres. According to the analyses, the pyrite is slightly cobaltoferous, the assay showing up to $0.15 \% \mathrm{Co}$. Chalcopyrite occurs in the fractures of pyrite and occasionally also as extensive displacing fields. It clearly favours the quartz-rich portions of the vein. Marcasite and hematite form banded displacement structures (Fig. 4.). Magnetite occurs in the vein parallel to it as schlieren that also contain abundant pyrite. The magnetite is idiomorphic towards pyrite and is often altered into martite along the cracks and margins of the crystals. Occasionally roundish pyrrhotite inclusions are noted in magnetite. A trace element analysis made on a magnetite sample yielded $0.01 \% \mathrm{Ti}$ and $0.02 \% \mathrm{~V}$. Arsenopyrite occurs as microscopic grains with which both $\mathrm{Bi}$-mineralization and tiny gold grains are associated. According to the electron microprobe determinations, the arsenopyrite assays $40.9 \% \mathrm{As}, 37.8 \% \mathrm{Fe}$ and $21.3 \%$ S. Ilmenite was encountered as random grains in gangue with some occasional hematite

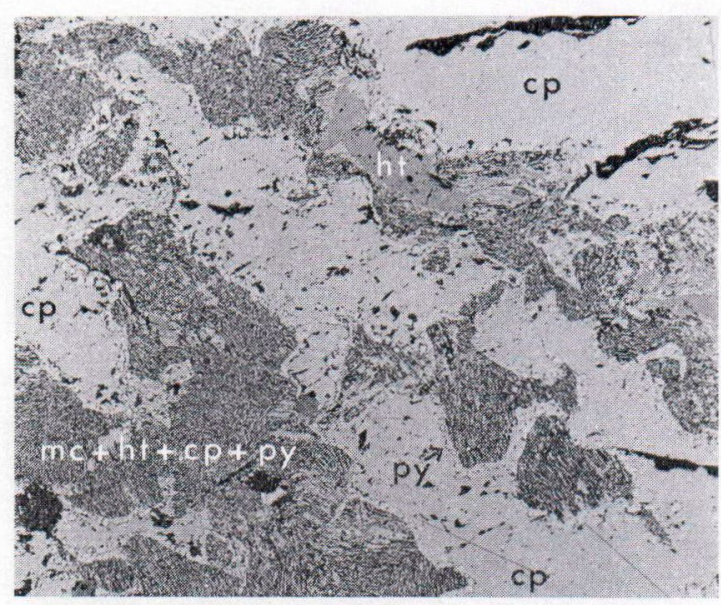

Fig. 4. Myrmekitic intergrowths of marcasite, pyrite, chalcopyrite and hematite with a pyritic rim against chalcopyrite, Magn. $30 \times$. py $=$ pyrite, $\mathrm{cp}=$ chalcopyrite, $\mathrm{mc}=$ marcasite, $\mathrm{ht}=$ hematite. inclusions. According to Dr. O. Kouvo, Geological Survey of Finland, the isotopic composition of lead in galena from a joint is: ${ }^{206} \mathrm{~Pb} /{ }^{204} \mathrm{~Pb}$ $16.33,{ }^{207} \mathrm{~Pb} /{ }^{204} \mathrm{~Pb} 15.69,{ }^{208} \mathrm{~Pb} /{ }^{204} \mathrm{~Pb} 35.68$. The model age $t_{6-7}$ is 1600 m.y. and $t_{8-4} 1750$ m.y. This age is not regarded as the absolute geologic age.

The high-grade central part of the vein is of almost compact magnetite-chalcopyrite ore. At a depth of about 10 metres the magnetite-predominant ore grades into a normal gangue-rich vein ore through the pyrite-predominant variant. The internal structure of the vein is distinctly banded owing to the layers that differ from each other in grain size and mineral composition. The layers are often parallel to the vein, although some internal layers meet the foot wall of the vein at a low angle as can be seen in the mine.

The vein abounds in small cavities whose walls are lined with calcite and quartz crystals on which magnetite has crystallized. Fine-grained hematite occurs on the surface of the latter. Large pyrite crystals were also encountered in the cavities. Fig. 5 depicts the shape of the vein on the mine levels and shows the distribution of copper and gold in the vein based on sludge sampling. The metals of economic importance attain their highest abundances in the thickest part of the vein. This can be traced from one level to the next. A strike-slip fault with a horizontal displacement of about 12 metres is also visible in the figure.

The vein has sharp contacts with the country rock. Grooves caused by movements and running parallel to the dip-slip direction were observed in the mine. The movements continued also after the emplacement of the ore, as is indicated e.g. by the cataclastic breaking of pyrite grains and occasional internal faults.

The final magmatic activities in the area are manifested by a diabase dyke emplaced in the above fault and in fractures parallel to it with some apophyses in the environment. The movements continued after the emplacement of the 


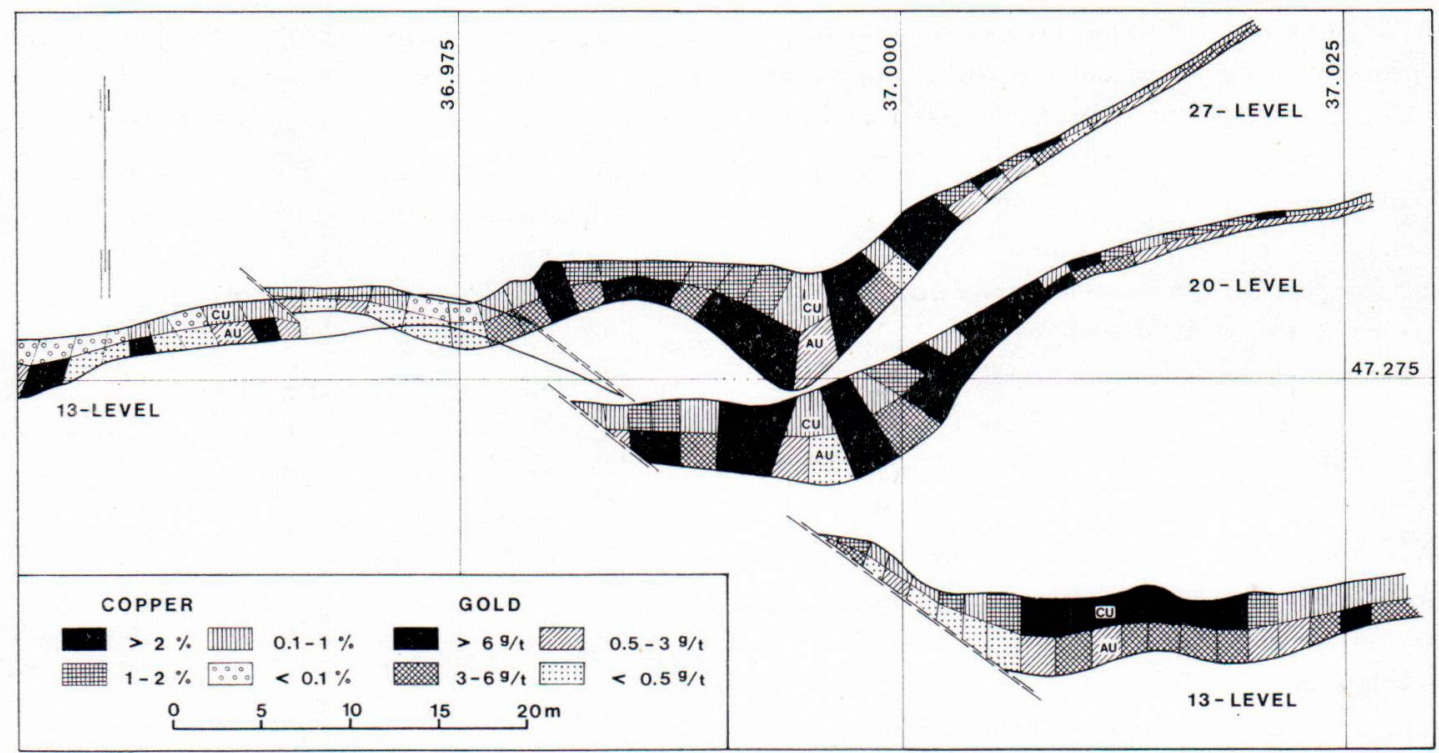

Fig. 5. Distribution of copper and gold in the vein on $+13-,+20-$ and +27 -levels. Values are based on sludge sampling during drifting.

diabase dyke, since there are signs of plastic deformation in the diabase dyke and in the ore. The diabase forms local boudinages in the ore.

The country rock of the ore vein is a finegrained albite diabase or greenstone altered into chlorite schist around the vein. Narrow crosscutting carbonate veins and small lenticles abound in this zone. Chlorite and carbonate are the predominant minerals in the schist, and the abundance of albite and pyrite varies considerably. From the vein outwards the schist grades into ophitic albite diabase through a massive chlorite-rock. The thickness of the altered zone varies from a few tens of centimetres to several metres. In general the zone runs on both sides of the vein.

The chlorite schist zone has been interpreted as a shear zone in which the formation of the veins took place in at least two stages. The narrow carbonate veins represent the older stage and are cut by the ore vein proper. Observations made in the mine on the attitude of the older veins in relation to the shear zone suggest that they are - at least partly — fillings of feather joints. The attitude of the joints shows that the movement in the shear zone was down the dip. The ore vein was emplaced only after the filling of the feather joints had been completed. It is thickest where, owing to the bend in the translation surface, the movement provided the largest open space.

\section{Discussion}

At Vinsa in the Peräpohja area about $20 \mathrm{~km}$ NE of Kivimaa there is a layered albitite intrusive, several tens of metres in thickness, in a coarse-grained albite diabase. In addition to albite, this body containes quartz and abundant magnetite as well as sulphide-bearing quartz veins. Albitite is cut by a c. $1 \mathrm{~m}$ thick quartz vein that is rich in chalcopyrite ( $\mathrm{Cu}$ c. $4 \%$ ). There is also abundant pyrrhotite in the vein as well as some pyrite and occasional cobalt pentlandite. The vein averages $3 \mathrm{~g} / \mathrm{t} \mathrm{Au}$. It resembles the Kivimaa deposit in its gold and copper abundances but differs clearly in the relative abundances of the other minerals. 
On the basis of the mineral assemblages in the sulphide-bearing veins cutting the metadiabases in North Karelia, Saksela (1960) has concluded that these veins were formed partly under pneumatolytic and partly under hydrothermal conditions. The observations made on the Kivimaa vein suggest only a lower temperature for formation. This is indicated by the lack of the higher temperature $\mathrm{Cu}$ assemblages in association with chalcopyrite as well as the high S/As ratio in the arsenopyrite, i.e. 0.52 as against the ideal 0.43 (see Clark, 1960).

The low $\mathrm{V}$ and $\mathrm{Ti}$ in the Kivimaa magnetite is a feature similar to that of the iron ores in the Misi area (Nuutilainen 1968). According to Nuutilainen, these ores were crystallized at low temperature from a spilitic hydromagma.

Barnes and Kullerud (1961) investigated the system $\mathrm{Fe}-\mathrm{S}-\mathrm{O}$ and noted that the common assemblage pyrite-pyrrhotite-magnetite can only occur in strongly alkaline solutions, and that by changing $\mathrm{pH}$ at constant $\mathrm{P}_{\mathrm{O}_{2}}$ one mineral may become unstable and another stable. According to experiments carried out by Roberts and Buchanan (1971), pyrrhotite converts to pyrite and magnetite in the presence of oxygen in aqueous solution after heating up to $180^{\circ} \mathrm{C}$. Hence, it is understandable that the assemblage magnetite-pyrite predominates in the Kivimaa vein that is characterised by carbonate and albite, whereas in the Vinsa quartz vein the above assemblage is replaced by pyrrhotite. Copper seems to be enriched in the quartz veins, while the cobalt-bearing pyrite appears to favour the carbonate-predominant veins.

In his numerous papers, Amstutz (for references, see Amstutz, 1959) has dealt with the mutual relationship between the spilitic rocks and the ore deposits. He came to the conclusion (Amstutz, 1958, p. 5) that: »later hydrothermal stages of spilites also lead to accumulation of rarer metallic elements such as copper, silver, gold, and probably also nickel and cobalt. Spilitic mineral deposits can be subdivided into oxyspilitic, sulphospilitic, and deposits of native metals». The Kivimaa vein does not represent any pure sub-type, but an intermediate one between the oxy-and sulpho-spilitic ore types.

In association with the Karelian metadiabases and greenstones numerous sulphide-bearing veins are known in North Karelia. They have been described by Saksela (1960), who considers them to be genetically related to the surrounding rocks. After studies in the Koli-Kaltimo area, Piirainen (1969) suggests that the above ore veins were formed as a result of a spilitic initial magmatism at the final stage of magmatic differentiation.

From the Peräpohja area near Kemi, Tegengren (1951) has described a gold-bearing ankerite vein in association with a hypabyssal greenstone. In his study on the albite diabases in the Enontekiö and Kittilä area, West Lapland, Meriläinen (1961) reports small sulphide- and oxide-bearing veins in the albitites. Vuorelainen et al. (1964) have described an uranium-bearing $\mathrm{Ni}-\mathrm{Se}-\mathrm{Te}$ mineralization in the Kuusamo area, NE Finland, in association with albite diabases.

The above studies indicate that there is a correlation between spilitic greenstone magmatism and mineralized veins. Two metallogenetic explanations can be offered for this correlation. A hydrothermal origin of the veins as a final phase of the initial magmatic episode, or a source bed concept, according to which the metal content of the veins were derived from the underlying sedimentary etc. rocks owing to a magmatic event. The authors prefer the former explanation. Depending on the condition of formation and the elemental abundances the mineral assemblages in the veins vary regionally and also locally within the veins. The emplacement of the veins was predominantly controlled by regional tectonics. The ore vein of Kivimaa at Tervola is the largest of this type of ore deposits encountered in Finland.

Acknowledgement - We gratefully acknowledge the aid given by Mr. Yrjö Vuorelainen in ore mineral identification. 


\section{REFERENCES}

Alarotu, O. (1970) Pienten malmien hyväksikäyttö. Vuoriteollisuus-Bergshanteringen, Vsk. 28, pp. 9194, Helsinki.

Amstutz, G. C. (1958) Spilitic rocks and mineral deposits. Missouri School of Mines Bull., Tech. Ser. 96, p. 11.

- (1959) Syngenese und Epigenese in Petrographie und Lagerstättenkunde. Schweiz. Min. Petr. Mitt. 39, pp. 1-84, (English translation in Internat. Geol. Rev. 3, 1961).

Barnes, H. L. and Kullerud, G. (1961) Equilibria in sulfur-containing agueous solutions, in the system $\mathrm{Fe}-\mathrm{S}-\mathrm{O}$, and their correlation during ore deposition. Econ. Geol. 56, pp. 648-688.

Clark, L. A. (1960) The Fe-As-S system: phase relations and applications. Econ. Geol. 55, pp. 16311652.

HÄrme, M. (1949) On the stratigraphical and structural geology of the Kemi area, Northern Finland. Bull. Comm. geol. Finlande 147, p. 60.

Meriläinen, K. (1961) Albite diabases and albitites in Enontekiö and Kittilä, Finland. Bull. Comm. Geol. Finlande 195, p. 75.

MrkmolA, A. (1949) On the geology of the area north of the Gulf of Botnia. Bull. Comm. geol. Finlande 146 , p. 64.
Nuutilainen, J. (1968) On the geology of the Misi iron ore province, Northern Finland. Ann. Acad. Sci. Fennicae. Ser. A. 111, 96, p. 98.

Pirrainen, T. (1969) Initialer Magmatismus und seine Erzbildung in der Beleuchtung des Koli-Kaltimogebiets. Bull. Geol. Soc. Finland 41, pp. $21-45$.

Roberts, W. M. B. and Buchanan, A. S. (1971) The effects of temperature, pressure and oxygen on copper and iron sulphides synthesised in aqueous solution. Min. Dep. 4, pp. 23-33.

SАкко, M. (1971) Varhais-karjalaisten metadiabaasien radiometrisiä zirkoni-ikiä (with an English summary). Geologi, Vsk. 23, pp. 117-119, Helsinki.

SAKSEla, M. (1960) Beiträge zur Kenntnis der sog. chloritischen Kupferformationen im fennoskandischen Grundgebirge. N. Jb. Miner., Abh. 94, pp. $319-351$.

Tegengren, F. R. (1951) Guldmalmsfynden vid Kemi. Acta Acad. Aboensis, Math. Phys. XVII. 7, p. 17.

Vuorelainen, Y., Huhma, A. and Häkl, A. (1964) Sederholmite, wilkmanite, kullerudite, mäkinenite and trüstedtite, five new nickel selenide minerals. Bull, Comm. Geol. Finlande 215, pp. 113-125.

Manuscript received, September 26, 1973. 